\title{
Aabenraa kommunes fotoarkiv
}

\author{
Af $K$. A. Flade.
}

Efter at Daguerre gjorde sin opfindelse omkring 1830, blev den tid, der fulgte, en billedalder. Personer og steder, dagligdagen og store begivenheder blev foreviget $i$ et utal af fotografier og er derved blevet reddet for eftertiden.

Fotografiet indtog fra den første tid en væsentlig plads i hjemmets udsmykning. Opsat på karton med fineste jugendstilornament-frise omkring og indrammet $i$ fornem ramme har mange fotografier smykket hjemmets vægge til langt op i det 20. århundrede. I Fortid og Nutid s skriver Hermansen, Ochsner og Paulsen ${ }^{1}$ ) $i$ en artikel om gamle fotografier: »Vore oldefædre og bedsteforældre interesserede sig for billederne på en anden måde end vi gør. Fotografierne blev først og fremmest brugt som pryd i hjemmene. Væggene var tæt behængt med dem. På skriveborde, etagerer og chatoller vrimlede det med opstillinger, udover hvad der var indsat i digre albummer, som var en fast underholdning, når familierne kom sammen. Anderledes $i$ dag. Vel blomstrer amat $\varnothing$ rfotografiet som aldrig f $\phi r$, men fotografierne er ikke mere på mode som udsmykning af værelserne; man går kun sjældent til fotografen, udveksler ikke portrætter og samler derfor heller ikke på dem.

De gamle fotografier er dermed kommet i farezonen. Mange er allerede gået til grunde, og dag efter dag skrider tilintetg $\phi$ relsen videre. Ved flytninger og oprydninger efter d $\phi d$ sfald kommer ganske vist mange gamle billeder for lyset, men efter at man som regel har moret sig over dem, bliver »det gamle stads ubarmhjertigt brændt eller smidt væk.

For at hindre, at det går således, er der rundt omkring af privatpersoner, museer, kommuner m. v. oprettet billedsamlin-

1) XVII bind, hefte 4. 


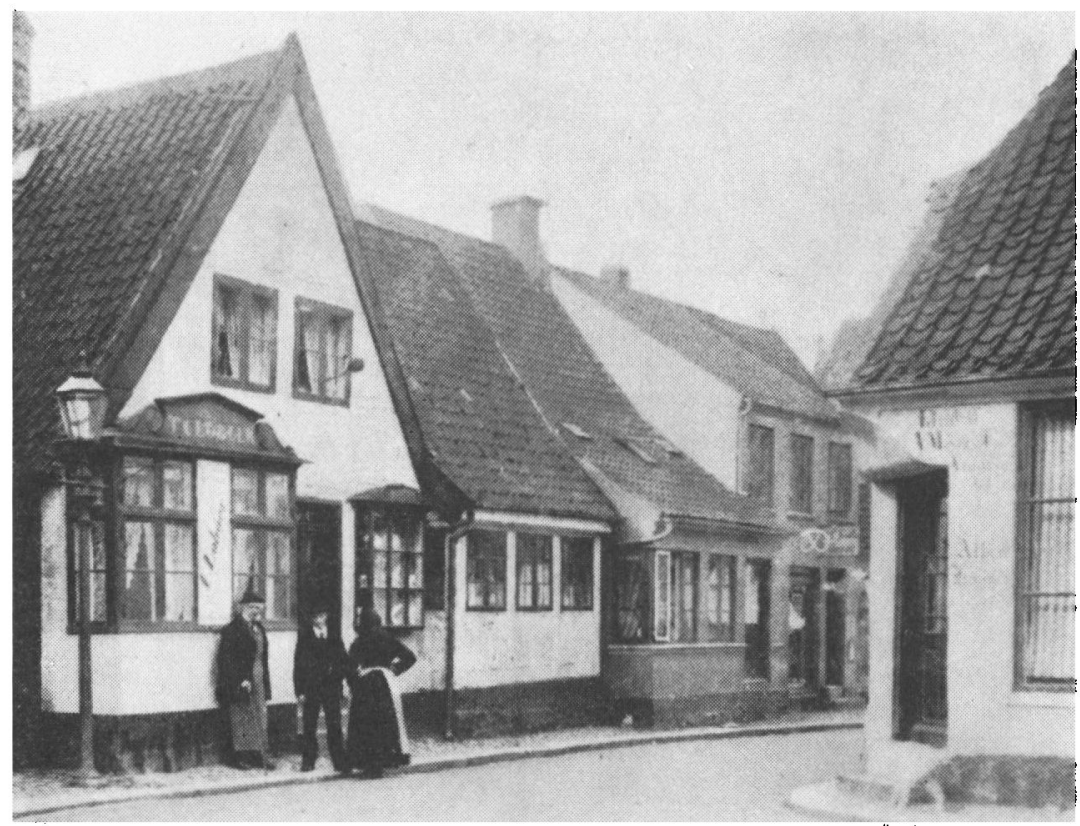

Billedet viser Vestergades udmunding $t$ Storetorv omkring ärhundredskiftet. Personerne pá billedet er formentlig den $i$ Aabenraa kendte handvarkerfamilie Lobger.

ger, som skal tage sig af indsamlingen af fotografier, negativer og lignende. For at skabe kontakt mellem disse interesserede er der nedsat et $\gg$ Landsudvalg for Indsamling af gamle Fotografier med rigsbibliotekar Palle Birkelund som formand.

Aabenraa kommunes fotoarkiv er egentlig begyndt som en støtte for det byplanmæssige arbejde, idet det hertil var af stor værdi at lære byens udvikling at kende. Samlingen af fotografier blev startet på ganske uvidenskabelig facon i 1948. Billederne indgår $i$ arkivet efterhånden som de fremkommer, $d$. v. s. nyt og gammelt imellem hverandre, idet man dog så vidt muligt fors $\emptyset$ ger at registrere fotografierne straks ved erhvervelsen efter f $\varnothing$ lgende skema.

Hvem - eller hvad - forestiller billedet.

Hvornår og hvor er det fotograferet.

Hvem har fotograferet det. 


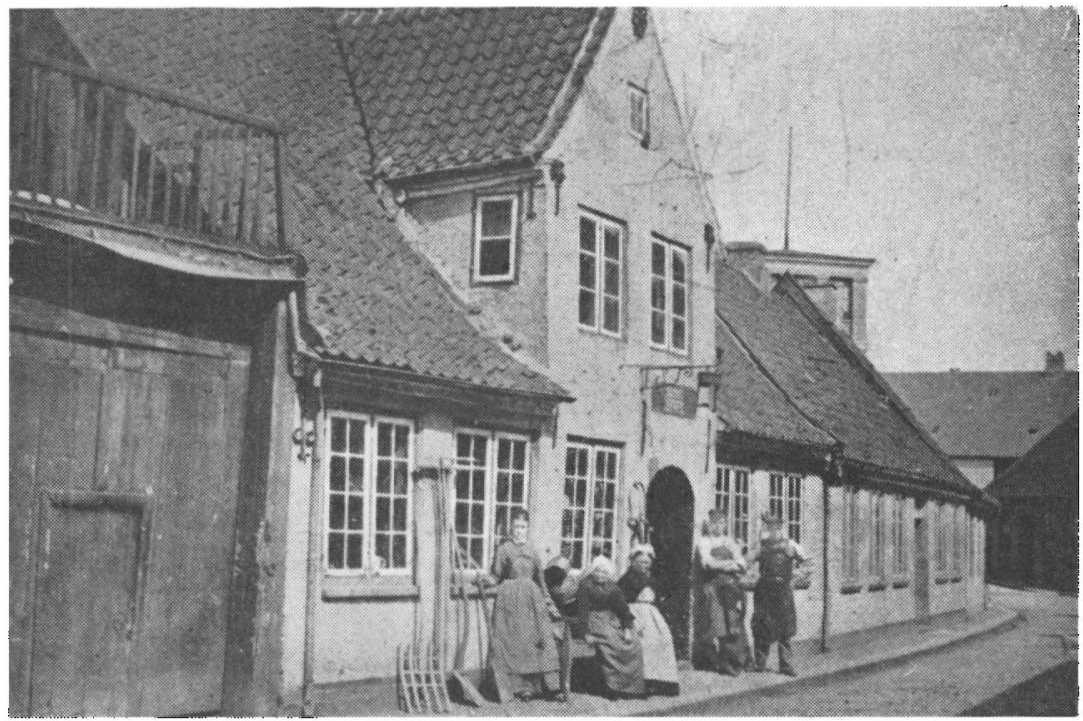

Et billede fra 1880, der viser det hus, der tidligere har ligget der, hvor nu ejendommen Sønderport 6 ligger. Sønderport $1-3$ (Schwennesens stiftelse) på den anden side af gaden, og denne $i$ samme stilart har sikkert vkladt hinanden ualmindelig godt. Personerne pó billedet er den daværende kendte familie Schröder m. fl.

Giverens eller ejerens navn.

Selve indsamlingen af billederne har for os været det vigtigste, idet vi går ud fra, at vi senere kan fả tid til at registrere billederne på en mere grundig måde, samt foretage en slags krydshenvisning mellem billeder med samme motiver, personer o. lign. Det er også hensigten senere at opdele billederne $i$ de tre grupper, som er foreslået af landsudvalget:

T: topografiske billeder.

P: portrætter.

S: saglige og andre billeder.

Billederne i kommunens fotoarkiv opbevares på bygningsinspektørens kontor $i$ stålskab. Billederne er med speciel fotolim »snapfix « heftet på ark af syrefri karton. Man er klar over, at denne opbevaringsmåde ikke er den mest hensigtsmæssige, men at man bør tilstræbe at få dem opbevaret $i$ syrefri konvolutter - helst gennemsigtige, da man på denne måde beskadiger billederne mindst og desuagtet vil være $i$ stand til at finde et be- 


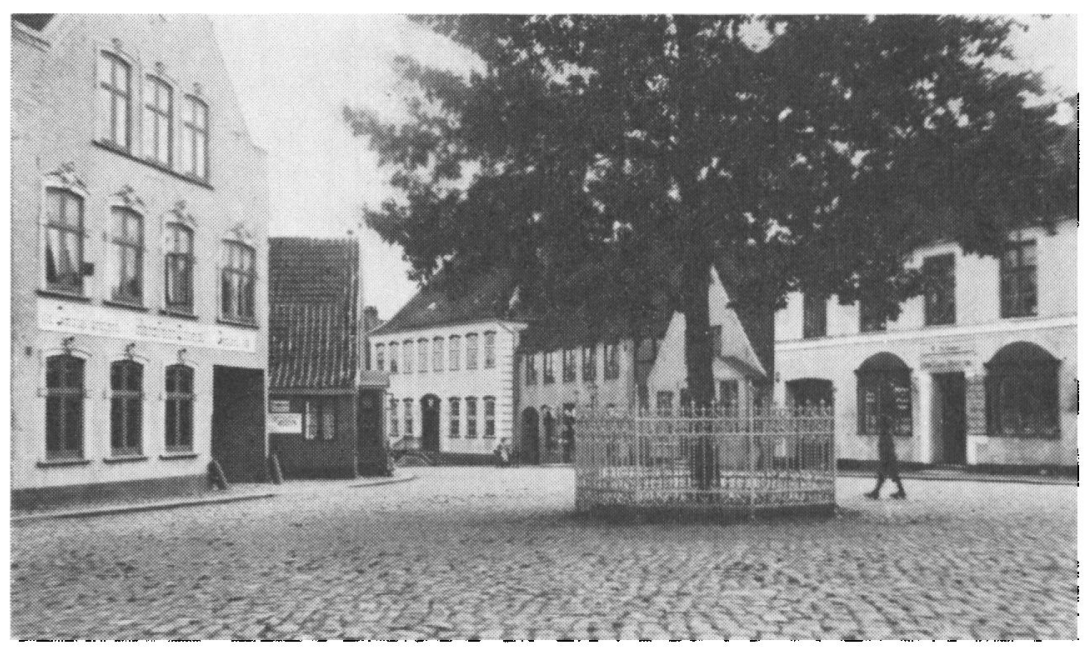

Billedet viser Søndertorv med sFriedenseiche», som blev plantet efter sefren $i$ krigen 1870/71. Egen har - uvis af hvilken grund - aldrig kunnet gro og er blevet fjernet efter den sidste krig. Billedet viser iфurigt en typisk række købstadsarkitektur $i$ de forskellige stilarter. Yderst til hojre barok, derefter renaissance, klassictsme og det fine rokokkohus, som dr. Beyer nu bor $i$.

stemt billede uden at skulle unders $\emptyset$ ge indholdet af mange konvolutter.

Hvordan fremskaffer man nu gamle billeder til et sådant arkiv? Vi har i Aabenraa f $\phi$ rst og fremmest unders $\emptyset \mathrm{gt}$, hvad der var at hente af gamle postkort ved boghandlerne. Det viser sig nemlig ofte, at gamle postkort er noget af det mest sejglivede der findes. Man vil sikkert endnu kunne gå ind i mange sønderjydske boglader og købe postkort fra omkring århundredskiftet eller i hvert fald fra genforeningen. I Aabenraa var vi også heldige $\mathrm{i}$ så henseende og fik mange interessante billeder til arkivet på denne måde. Det største »fund « af billeder fik vi imidlertid fra boghandler Wohlenberg i Aabenraa. Det viste sig, at Wohlenbergs fader - der også var boghandler og dygtig fotograf havde efterladt sig en stor samling negativer på glasplader med billeder fra Aabenraa og omegn. Disse plader lånte vi til afkopiering og fik derved mange gode billeder fra årene 1900-1914.

Efterhånden fik aviserne interesse for sagen, og de har været meget imødekommende og nævnt sagen mange gange. Et enkelt 


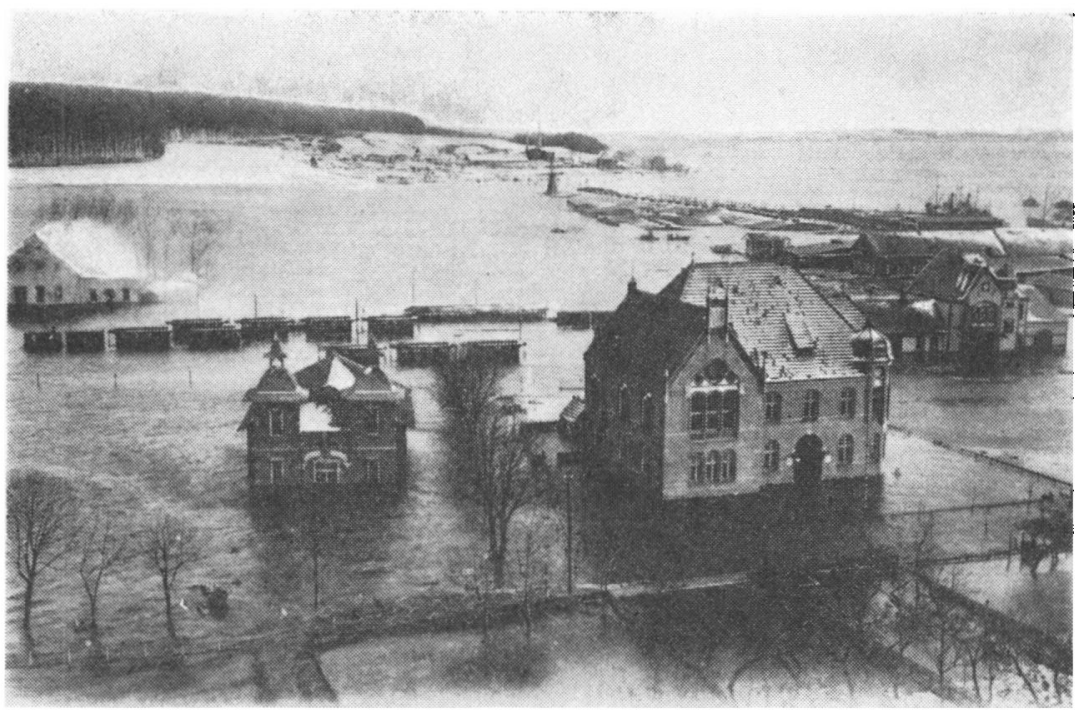

Hillede der viser oversvommelsen nytüsnmt 1904/05. Man ser hele arealet omkring amtshuset og rulebilstationen (den daverende amtsbanestation) under vand. Tretbygningen ved siden af amtshuset er oTurnhalle», den blev senere flyttet ud pá strition on endte sin tllberelse som husvildebarak.

blad har endog $i$ en længere serie bragt billeder fra arkivet, hvorved interessen blandt publikum har vist sig at være stor for sagen, og mange har afleveret deres billeder til samlingen, når de igennem aviserne har erfaret, at vi var interesseret $\mathbf{i}$ dem.

En anden side af samleropgaven - ikke den mindst vigtige - er så tit som muligt at fremvise billederne, f. eks. i form af lysbilleder som illustration til historiske, arkitektoniske, folkelige eller andre foredrag. Hvad dette angår har vi været meget heldige i Aabenraa. En række foredragsholdere har gjort brug af vore billeder og navnlig har overassistent $H$. Jacobsen, Aabenraa folkeregister — som selv er meget interesseret i billedarkivet ved mange foredrag $i$ studiekredse og ved almindelige underholdningsaftener anvendt billeder fra arkivet. Hr. Jacobsen har ved enhver lejlighed reklameret for arkivet, og ethvert af hans foredrag er normalt blevet efterfulgt af et kølvand af gamle billeder.

Det er jo ikke alene gamle billeder, der har interesse i forbindelse med et sådant arbejde. Man bø̆r således altid sфrge for at 
holde samlingen á jour ved at gennemfotografere landskabs- og gadebilleder, huse $m$. v., forinden ændringer foretages, som $\mathbf{f}$. eks. f $\varnothing \mathbf{r}$ opf $\varnothing$ relse af nybygninger eller - hvad der er endnu vigtigere - for nedrivninger af huse, omlægning af gader, faldning af vejtraer o.s.v. Det er $\mathrm{i}$ virkeligheden forbavsende så hurtigt en hys fysiognomi ændrer sig, hvilket vi i vort knap 10 år gamle arkiv har talrige eksempler på.

Efterhånden har billedsamlingen antaget et ret anseeligt omfang, idet den omfatter ca. 1800 billeder, og hensigten er selvf $\phi$ lgelig, at den engang kan indgå $i$ et virkeligt byhistorisk arkiv for Aabenraa. De første spæde skridt $i$ så henseende kan siges at være gjort, idet vi af og til $-\mathrm{i}$ forbindelse med jagten efter gamle billeder - st $\not d e r$ på interessante ting, som vi uden videre indlemmer i samlingen, men som jo egentlig hører hjemme i det hyhistoriske ankiv, og som selvf $\emptyset$ lgelig også f $\emptyset \mathbf{r}$ eller senere ender der.

Jeg kan således for eksempel nævne:

En serie naverpas fra omkring $1910 \mathrm{og}$ et $\gg$ medlemskort $\ll$ til Apenrader Todtengilde fra 1887.

Vor mening med at samle billederne og vort $\phi$ nske dermed er, at billederne må blive benyttet og derved kendt for så mange som muligt, og vi har da også haft den glæde, at man i stor udstrækning har fundet vore billeder brugbare til illustration af $b \phi-$ ger, årsskrifter, avisartikler, jubilæumsskrifter m. v., og sidst har vi nu haft den glæde, at det kongelige bibliotek har udbedt sig lov til at kopiere de omtalte $\mathbf{4 0 0}$ glasplader fra den wohlenbergske samling.

Vi håber på fortsat forståelse for vort arbejde, således at folk vil komme til os med de billeder, som de ikke selv har brug for mere - ligegyldigt hvad billederne så end forestiller. At vi stadig kan glæde os ved, at der vises arbejdet interesse, har vi fået synligt bevis for, idet der netop i de seneste dage til kontoret er hlevet indleveret en hel kasse med gamle fotografier.

Det er virkelig et misundelsesværdigt job at gå i gang med en sådan kasse fuld! 